\title{
Social Welfare Effect \\ Of Ghana Cocoa Price Stabilization: Time Series Projection And Analysis
}

Uwakonye Matthew, (Email: uwakonyem@uhd.edu), University of Houston-Downtown Asghar Nazemzadeh, (Email: nazemzadeh@dt.uh.edu), University of Houston-Downtown Osho Gbolahan Solomon, (Email: oshos@uhd.edu), University of Houston-Downtown William J. Etundi, (Email: wetundi@hal-pc.org), Texas Southern University of Houston

\begin{abstract}
Wide fluctuations in the price of an agricultural product are often correlated with inelasticity of supply and/or demand for the product. The issue of whether such fluctuations are desirable or undesirable for cocoa producing countries has still to be settled. Among those who believe that price fluctuations are undesirable and should be reduced, there are divergent opinions as to how these fluctuations should be reduced. The objective of this study is to determine the effect of price stabilization on the economic welfare of producers and consumers of Ghana cocoa. Hence this study will estimate supply and demand functions for Ghana cocoa. Parameter estimates will then be used to predict social welfare gains and losses from increased cocoa price stabilization. On the demand side an increase in disposable income influences consumers positively in buying cocoa products. On the producer supply side, independent variable explained 86.5 percent of the variations in supply of cocoa by farmers. Welfare gains measured in this study do not account for additional storage costs that would be incurred by Ghana Marketing Board to make complete prices stabilization operational. Given rather unstable supply and demand functions for Ghana cocoa as indicated by their respective variances, the buffer inventory required by the Ghana Marketing Board to stabilize Ghana cocoa prices would likely be large, so is the resource cost of maintaining that buffer inventory. With respect to welfare implications, this study supports the argument that price stabilization will benefit Ghana cocoa farmers as well as consumers. Society as a whole benefits by the net gain in welfare based on Massel's model.
\end{abstract}

\section{INTRODUCTION}

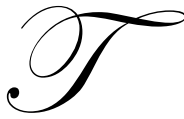

he problem of price fluctuations in primary product markets has been the subject of many studies. A wide fluctuation in the price of an agricultural product is often correlated with inelasticity of supply and/or demand for the product. According to Abbott (1960) when an inelastic demand is associated with a highly inelastic supply, the result is large fluctuation in price whenever supply of demand of the product changes. The issue of whether such fluctuations are desirable or undesirable for cocoa producing countries has still to be settled. Many cocoa producing countries have adopted schemes to dampen effect of price fluctuations in cocoa export markets on their domestic economies. Among those who believe that price fluctuations are undesirable and should be reduced, there are divergent opinions as to how these fluctuations should be reduced (Dercon, 2000). Ghana has adopted the buffer stock scheme by using a marketing board. This board has been operating for many years but the rationale for its introduction, its pricing policies, and its effectiveness are still being questioned. The objective of this study is to determine the effect of price stabilization on the economic welfare of producers and consumers of Ghana Cocoa. Hence, this study will estimate supply and demand functions for Ghana cocoa. Parameter estimates will then be used to predict social welfare gains and losses from increased cocoa price stabilization. Additional resource costs of increased storage to implement such a program are not included in the analysis. 


\section{MODEL SPECIFICATION AND PROBLEMS OF ESTIMATION}

The purpose of this section is to present an economic model which represents the supply and demand for Ghana Cocoa, to present the statistical procedure used, and to discuss problems of estimation. The economic model is first presented, followed by the statistical models and the estimation procedure.

Demand for commodities consumed directly by consumers is properly viewed in the context of utility theory. Consumers gain utility or satisfaction from consumption of commodities. In purchasing a commodity, a consumer attempts to buy the commodity from which he gets the greatest satisfaction in relation to the price of that commodity. Consumers are limited in the amount of good, which they can purchase and, as a result, must make choices among various goods. These choices are influenced by preferences, income and by prices of goods available (Ahn and Reinsel, 1990).

Properties of the demand function for a commodity indicate that quantity demanded is inversely related with changes in the price of the commodity. Increases in the price of the commodity results in a substitution away from that commodity, other things being equal.

Since the demand function is defined to pertain only to a particular time, its shape and position are likely to change with the passage of time. A shift in the demand function is normally accounted for by a change in the value of some of the variables that affect demand. For example, a rise in consumer income will lead to a rightward shift in the demand curve for a normal good, so will a change in price of substitutes and an increase in advertising. Two effects determine the shape of the demand curve: a substitution effect, and an income effect. The demand for an intermediate product such as cocoa is derived from the demand for cocoa based finished products. In other words, the elasticity of demand for cocoa as an intermediate product in production is a function of final demand elasticity, elasticity of substitution among inputs in production, and supply elasticity of other factors used in the production of the cocoa based product. If these other factors are perfectly elastic in supply, then demand for cocoa at the farm is dependent on the demand for the final product and the elasticity of substitution among inputs in the production of the cocoa based product (Baumol, 1977).

The structure of a market for a commodity depends not only on the nature of demand, but also on the nature of supply factors (Fraser, 1992). If a firm in a competitive industry produces one commodity, it can be shown that the firm's supply curve for that commodity is identical with its marginal cost curve above the minimum average variable cost (Nerlove, 1958).

At the micro level, a shift in the supply function for an individual firm is characterized by a change in the planned level of output at a given price without any change in the decision making environment faced by the firm (Morduch, 1995). Included in the environment are factors such as the production function of the firm, managerial abilities, and the institutional setting in which the firm operates.

Variable classified as supply shifters include: 1) prices of inputs or factors, 2) prices of commodities competing in production, 3) price "expectation" of the commodity, 4) number and sizes of firms, and 5) for agricultural goods, weather.

\section{STATISTICAL MODEL: THE DEMAND RELATION}

Based on the theory of demand for a commodity, it is postulated that quantity of Ghana cocoa beans demanded (derived from consumer demand for cocoa based products) by the world consuming nations in a given year is a function of disposable incomes of people in consuming nations, world price of cocoa, price of other close substitutes or complements, and any "buffer stock" available to buyers in the given period. ${ }^{1}$ A priori expectations

\footnotetext{
${ }^{1}$ Buffer Stock is defined in this analysis as the difference between the amount of cocoa beans purchased by consuming nations, and the amount actually consumed in a given year. Cumulative buffer stock is not used in this study because date used were collected from different sources, and some of the original amount of cocoa beans purchased by consuming nations may have disappeared or been transferred to other uses which are not reported. As a result, cumulative buffer can not be calculated statistically, hence current differences are used.
} 
are that quantity demanded will be positively related to income (cocoa is a normal good), and negatively related to the price of cocoa. Theory suggests that demand is positively related to the price of substitutes and negatively related to complements (HWA, 1979). Similarly, demand for cocoa is expected to be negatively related to available buffer stock. This is due to the fact that an increase in buffer stock of cocoa shifts the demand curve to the left, reducing the quantity of cocoa demanded.

\section{STATISTICAL MODEL: THE SUPPLY RELATION}

The supply model of the cocoa marketing board has two components: supply of cocoa produced by farmers and sold to the Ghana cocoa marketing board, and supply sold by the Ghana cocoa marketing board. Thus over time, quantity sold by the board is influenced by supply decisions of farmers. It can be postulated from the theory of supply that supply of Ghana cocoa to consuming nations by the cocoa marketing board is a function of world export price of cocoa, price of other competing commodities that could be grown by producers, and weather. The price of competing commodities and weather are associated with producer behavior. Response to world market price of cocoa is determined by the cocoa marketing board. This is due to the fact that the opportunity cost of keeping inventory will be an incentive to the marketing board to increase supply. Also, given an objective to keep prices stable, the price of cocoa acts positively to increase and decrease quantity supplied.

As theory predicts, supply of cocoa is expected to be negatively related to the price of competing commodities. Weather is an especially difficult variable to handle in explaining supply relations. Although it acts as a supply shifter, the expected direction of its effects may be uncertain. For example, heavy rainfall could result in cocoa diseases and harvesting problems. Likewise, very low rainfall could result in lower yield in a given year.

\section{STUDY VARIABLES}

In the simultaneous demand and supply model, quantity is the total amount of Ghana cocoa imported by consuming nations in the same year. Price is the average annual New York spot price of Accra cocoa. Annual prices are deflated by the U.S. consumer price index (base year is 1985) to convert them to constant prices.

The principal substitute for or compliment to cocoa in production is sugar (Grilli and Yang, 1988). It is a substitute in that sugar may replace cocoa in the manufacture of products that compete with cocoa based products, such as non-chocolate candies or carbonate beverages. It is a compliment in that sugar and cocoa are utilized in the manufacture of chocolate confectionary. The deflated annual New York wholesale spot price of sugar is used as the explanatory variable.

Annual U.S. disposable income is used as a proxy for world disposable income for two reasons: 1) U.S. is a typical cocoa consuming nation, and 2) annual changes in total income of consuming nations is dominated by changes in U.S. income.

Two supply equations are estimated in this study: total amount of Ghana cocoa produced by farmers, and the amount of cocoa exported by Ghana cocoa marketing board to consuming nations in a given year. Quantities supplied by the board and quantities demanded by consuming nations are equal. The amount of cocoa produced by farmers in a given year depends on prices established by the cocoa marketing board, potential output, and weather. Potential output, measured as a three-year moving average of total producer output, is used as a proxy for price of competing commodities and all other agronomic and economic factors in the production equation. Similarly, supply of cocoa by the cocoa marketing board is a function of world price of cocoa, price of other competing commodities, and weather.

\section{ESTIMATION PROCEDURE}

The demand for Ghana cocoa by consuming nations and the amount supplied by the cocoa marketing board are assumed to be simultaneously determined subject to the set of exogeneous variables specified below. Two stage 
least squares (TSLS) method of regression was used to estimate the statistical relationships embodying this simultaneity. TSLS gives consistent parameter estimates whenever simultaneity is involved.

The linear functional form of the ordinary lease squares regression (OLS) was used to estimate producer supply equation. The structural supply and demand functions of the simultaneous equations are as follows:

\section{Structural Equations}

Supply:

Demand:

Equilibrium condition:

$$
\begin{aligned}
& \mathrm{Qs}=f(\mathrm{Pw}, \mathrm{Pc}, \mathrm{W}, \mathrm{u}) \\
& \mathrm{Qd}=f(\mathrm{Pw}, \mathrm{Ps}, \mathrm{Yd}, \mathrm{Qwb}, \mathrm{v}) \\
& \mathrm{Qs}=\mathrm{Qd}=\mathrm{Q}
\end{aligned}
$$

\section{The reduced form of the functions}

$\mathrm{Q}=\boldsymbol{f}(\mathrm{Pc}, \mathrm{Ps}, \mathrm{Yd}, \mathrm{W}, \mathrm{Qwb}, \mathrm{x})$

$\mathrm{Q}=\boldsymbol{f}(\mathrm{Pc}, \mathrm{Ps}, \mathrm{Yd}, \mathrm{W}, \mathrm{Qwb}, \mathrm{y})$

\section{Producer supply equation:}

$\mathrm{Qp}=\mathrm{f}\left(\mathrm{Pc}, \mathrm{W} \mathrm{Q}^{\prime}, \mathrm{z}\right)$

Where Qp is the total cocoa produced by farmers in a given year, Qs is the total cocoa supplied by the cocoa marketing board for a given year, Qd is the total cocoa demanded by consuming nations for a given year, Pw is the real average spot price of cocoa (deflated by CPI U.S.), Pc is the real average price of corn (deflated by CPI U.S.), $\mathrm{Pp}$ is the real producer price of cocoa paid by marketing board (deflated by CPI Ghana), Ps is real average price of sugar (deflated by CPI U.S.), Yd is the real disposable U.S. income (deflated by CPI U.S.), Qwb is the world cocoa buffer stock, $\mathrm{W}$ is the weather, $\mathrm{Q}^{\prime}$ is the potential output, and $\mathrm{u}, \mathrm{v}$ are assumed to individually have zero autocorrelation, constant variance, normal distributions, and zero means. However, $\mathrm{u}$ and $\mathrm{v}$ are assumed to be correlated. $\mathrm{x}$ and $\mathrm{y}$ are random disturbances (reduced form functions), also assumed normally distributed with zero means. Similarly, $\mathrm{z}$ is a random disturbance (producer supply), assumed normally distributed with zero mean.

\section{Massel Model}

This model allows for shifts in the demand and the supply curves. Massel assumes that price stabilization is achieved by a buffer stock scheme (Massel, 1979). The supply and demand functions are assumed to be:

$\mathrm{S}=\alpha \mathrm{P}+\mathrm{x} \quad \alpha \geq 0$

$\mathrm{D}=-\beta \mathrm{P}+\mathrm{y} \quad \beta \geq 0$

Where $\mathrm{S}$ is the quantity of the commodity supplied, $\mathrm{D}$ is the quantity demanded, $\mathrm{P}$ is the price of the commodity, and $\alpha$ and $\beta$ are constants, and $\mathrm{x}$ and $\mathrm{y}$ are the shift terms which are normally distributed with nonzero expected values. Price is stabilized at the mean value which is assumed known from the distribution of $\mathrm{x}$ and $\mathrm{y} . \mathrm{x}$ and $\mathrm{y}$ are assumed to be uncorrelated, i.e., $\operatorname{cov}(\mathrm{x}, \mathrm{y})=0$. The mean price under competitive condition is:

$\mu \mathrm{p}=\mathrm{E}(\mathrm{P})=\frac{\mu \mathrm{y}-\mu \mathrm{x}}{\alpha+\beta}$

where: $\quad \mu \mathrm{x}=\mathrm{E}(\mathrm{x})$

$$
\mu \mathrm{y}=\mathrm{E}(\mathrm{y})
$$

Using consumer and producer surplus as a measure of welfare, Massel shows that for any one year the expected producer gain from stabilization is:

$\mathrm{E}(\mathrm{Gp})=\frac{(\alpha+2 \beta) \text { oxx }-\alpha o ̛ y y}{2(\alpha+\beta)^{2}}$ 
The expected gain to consumers is:

$\mathrm{E}(\mathrm{Gc})=\frac{(2 \alpha+\beta) \text { oyy }-\beta \text { oxx }}{2(\alpha+\beta)^{2}}$

The net gain from price stabilization is:

$$
\begin{aligned}
& \mathrm{E}(\mathrm{G})=\frac{\sigma \mathrm{xx}+\text { oyy }}{2(\alpha+\beta)} \quad=\frac{(\alpha+\beta) o p p}{2} \\
& o p p=\underset{(\alpha+\beta)^{2}}{\operatorname{oxx}+o y y}
\end{aligned}
$$

where: $\quad$ oxx $=\operatorname{Var}(\mathrm{x})$

$$
\begin{aligned}
& \text { oyy }=\operatorname{Var}(y) \\
& \text { oxy }=\operatorname{Cov}(x, y)=0
\end{aligned}
$$

Results of Massel's model imply that producers are more likely to gain from stabilization the larger the supply variance (oxx) relative to the demand variance (oyy). The likelihood of producers gaining is greater the steeper the supply curve (decreased $\alpha$ ) relative to the demand curve. In the limiting case of either a vertical supply curve or a zero demand variance, producers cannot lose from price stabilization. Consumers are more likely to gain, the larger the demand variance relative to its supply variance and the steeper the demand curve (decreased $\beta$ ) relative to the supply curve. In the limiting case of either a vertical demand curve or a zero supply variance, consumers cannot lose from price stabilization.

In conclusion, the concepts of producer and consumer surplus are accepted traditional criteria for evaluating price stabilization. In other words, the source of commodity price instability is a critical factor in determining whether producers or consumers gain from price stabilization.

\section{STUDY RESULTS AND DISCUSSION}

This section presents results of the estimated simultaneously determined supply and demand equations for Ghana cocoa, and producer supply equation for the period 1980-2002. The equations estimated are reasonably successful in explaining supply and demand for Ghana cocoa. Estimated coefficients and their values are presented in Tables 1 and 2. Signs of the coefficients are not statistically different from zero at 5 percent level of significance.

An increase in disposable income influences consumers positively in buying cocoa products. An increase in the price of sugar (which results suggest to be a gross substitute for cocoa) in a given year may induce consumers of sugar based candies to shift to chocolate and other cocoa based confectionaries ( $t$-value of 0.76 ).

Amount of rainfall in a given year showed a positive, though not significant, relationship with supply. This is consistent with the argument that it is one of the factors contributing to reduction of cocoa production in recent years during which Ghana and other West African countries have been experiencing droughts. The price of corn, used as a proxy for an alternate crop to producers, relates negatively with the supply of cocoa. This is interpreted that an increase in alternate crop prices relative to the price of cocoa in a given year will induce producers to shift to the production of alternative crops. Results of this analysis also indicates that an increase in the buffer stock of consuming nations has decreased or no effect on demand ( $t$-value of 0.26). A negative sign is consistent with theoretical expectations.

On the producer supply side, independent variables explained 86.5 percent of the variations in supply of cocoa by farmers. The value of the Durbin-Watson Statistic (3.19) is inconclusive of the null hypothesis of zero autocorrelation of residuals at 5 percent of confidence. Potential output is significantly and positively related to 
current year supply. A summary of own price elasticities derived from the estimated equations are presented in Table 3. Estimates from other studies are also presented.

Comparing elasticities estimated in this study with those from other studies, (Table 3), own price elasticity for the simultaneously determined demand equation is much lower than the estimates of Okorie and Blandford (1997), and Berham (1978). Berhman's estimates, however, appear rather high. With respect to income elasticities, the estimate in this study is comparable with Berhman's (1978) estimates, but higher than estimates of Okorie and Blandford (1997) and that of Berham (1965). Berhan's income elasticity of demand estimate for the U.S. is, however, large, in absolute size, but negative in sign. The own price elasticity estimate for the producer supply equation is very low compared with the estimate of Bateman (1968) for Ghana.

In addition to price stabilization, there is the issue of revenue stabilization to cocoa farmers. Brook and Grilli (1977) have asserted that when both supply and demand are price inelastic over a relevant range, price stabilization can also stabilize export revenue in a market situation with relatively unstable supply. This study shows that both supply and demand for Ghana cocoa are highly price inelastic. It can therefore be occluded that attempts by the marketing board to stabilize prices will also stabilize revenue for cocoa farmers.

\section{WELFARE EFFECTS}

Welfare gains from price stabilization are estimated using Massel's model. Equations and numerical values used are given in appendix A; it is not possible to interpret absolute values calculated. However, it is possible to conclude that producer and consumer welfare gains from price sterilization will be positive. In other words, producer and purchasers of Ghana cocoa gain from price stabilization. Producer gains are, however, relatively greater than purchaser gains, social welfare, measured by the sum of producer and purchaser gains, will be increased.

Welfare gains measured in this study do not account for additional storage costs that would be incurred by the Ghana marketing board to make complete prices stabilization operational. Given rather unstable supple and demand functions for Ghana cocoa as indicated by their respective variances, the buffer inventory required by the Ghana marketing board to stabilize Ghana cocoa prices would likely e quite large. The resource costs of maintaining that buffer inventory would also be quite high. Whether welfare gains measured in this study are offset by additional resource costs of storage is not known. This suggests additional research information is required before Ghana cocoa prices stabilization can be recommended as yielding unequivocably net welfare gains to producers, consumers, or society as a whole.

\section{SUMMARY AND CONCLUSION}

Empirical results suggest that the price of cocoa has minimal impact (relatively inelastic functions) on both the cocoa marketing board and consuming nations on their decisions regarding the supply and demand for Ghana cocoa. An increase in alternate crop prices relative to the price of cocoa in a given year is likely to increase the quantity supplied while it decreases quantity demanded. An increase in alternate crop prices relative to the price of cocoa in a given year will induce producers to shift to the production of alternate crops. This is probably one of the contributing factors to the decline in cocoa production in Ghana in recent years.

The different time periods covered and different model specification of other studies make a complete evaluation of the various elasticity estimates difficult. However, it can be said that in all the studies, the price elasticity of supply and demand for cocoa is inelastic. Similarly, income elasticity of demand, estimated in all but one of the studies are inelastic, results of the elasticity estimates show that both supply and demand factors contribute to price instability in the Ghana cocoa industry.

With respect to welfare implications, the study supports the argument that price stabilization will benefit Ghana cocoa farmers as well as consumers. Society as whole benefits from cocoa price stabilization as evidenced by the net gain in welfare based on Massel's model. These measured welfare gains do not include any additional storage costs resulting from price stabilization. 
Table 1. Simultaneous Equations Estimates of Structural Supply and Demand Relations and Estimated Reduced Forms for Ghana Cocoa, 1980-2002.

\begin{tabular}{l|c|c|c|c}
\hline \multicolumn{1}{c|}{ Variable } & \multicolumn{2}{c}{ Structure } & \multicolumn{2}{c}{ Reduced Form } \\
\hline Constant Term & Supply & Demand & Quantity Supplied & Price \\
Pw & $365.24 * *(2.26)$ & $387.91^{* * *}(3.53)$ & $296.64 * * *(3.02)$ & $-250.11(.65)$ \\
Ps & $.26 *(1.74)$ & $-.54 * *(2.04)$ & & $1.15(1.05)$ \\
Pc & $-2.12 * * *(4.09)$ & $.58(.76)$ & $-.02(.09)$ & $3.96 * *(2.38)$ \\
Yd & & $.39 * *(2.63)$ & $1.39 * *(4.42)$ & $.22(.72)$ \\
Qwb & & $-.08(.26)$ & $.77(1.55)$ & $.36(.60)$ \\
W & $.27(.31)$ & & $.29 *(1.94)$ & $1.74 *(1.96)$ \\
$\mathrm{R}^{2}$ & .663 & .598 & .740 & .32 \\
$\mathrm{~F}^{\mathrm{a}}$ & 19.0 & 10.42 & 15.35 & 2.5 \\
$\mathrm{DW}^{\wedge} \mathrm{b}$ & & & 1.24 & 1.02 \\
\hline
\end{tabular}

Note: Absolute valued of "t" statistics are in parenthesis. Coefficient is statistically different from zero at the significance level of 10 percent $(*), 5$ percent $(* *)$, and 1 percent $(* * *)$.

${ }^{\text {a }}$ Calculated F-Statistics.

^b Calculated Durbin-Watson Statistics.

Table 2. Estimated Producer Supply Equation for Ghana Cocoa, 1980-2002

\begin{tabular}{c|c}
\hline Variable & Supply \\
\hline Constant Term & $-85.80(1.18)$ \\
Pp & $.022(.75)$ \\
W & $.356(1.20)$ \\
$\mathrm{Q}^{\prime}$ & $1.06 * * *(7.54)$ \\
$R^{2}$ & .865 \\
$\mathrm{~F}^{\mathrm{b}}$ & 51.15 \\
$\mathrm{DW}^{\mathrm{c}}$ & 3.19 \\
\hline
\end{tabular}

Note: Absolute values of " $t$ " statistics are in parenthesis.

$\mathrm{a}^{* *}$ Coefficient is statistically different from zero at the 1 percent level of significance.

${ }^{\mathrm{b}}$ Calculated F-Statistics.

${ }^{\mathrm{c}}$ Calculated Durbin-Watson Statistic.

Table 3. Elasticity Estimates of Uwakonye et al. and Other Studies

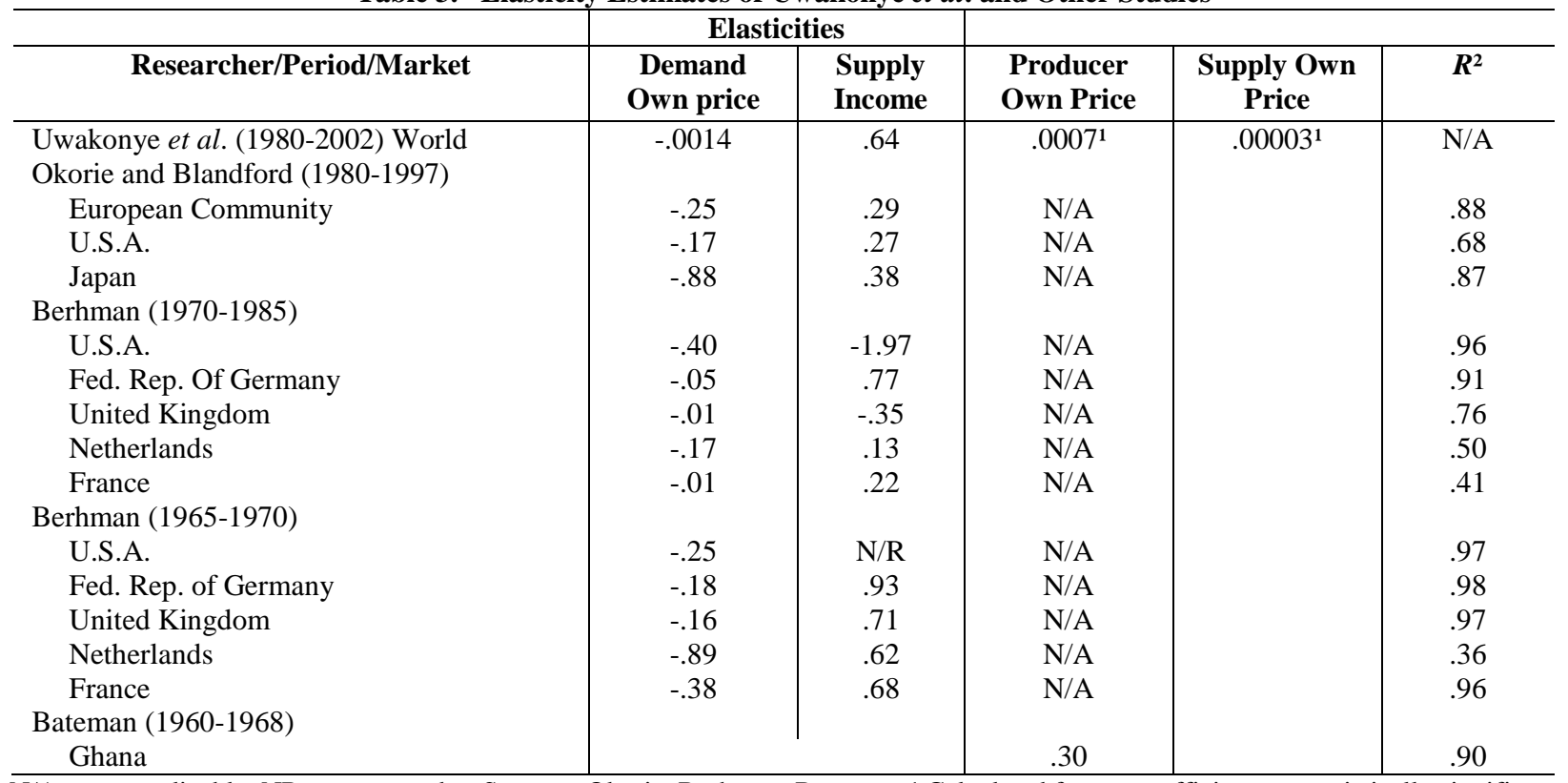

N/A = not applicable; NR = not recorder; Sources: Okorie, Berhman, Bateman; ${ }^{1}$ Calculated from a coefficient not statistically significant at .05 level 


\section{REFERENCES}

1. $\quad$ Abbott, Lawrence, Economics and the Modern World, Harcourt, Brace and World, Inc. N.Y., 1960.

2. Ahn, S. K. and G. C. Reinsel, 1990, "Estimation of partially non-stationary autoregressive models," Journal of the American Statistical Association, 85, 813-23.

3. Bauer, P.T. and H. Myint, "The Hidden Cost of Commodity Price Stabilization." The Banker, Vol. 126, Dec. 1976 pp. $1423-1426$.

4. Bauer, P.T. and Paish, "The Reduction of Fluctuations, in the Incomes of Primary Producers," Economic Journal, Vol. 62, No. 248, (Dec. 1953) pp. 750-780.

5. Baumol, William J., Economic Theory and Operations Analysis, $4^{\text {th }}$ Edition, Prentice-Hall, Inc., Englewood Cliffs, N.J., 1977.

6. Brook, E. M. and Enzo Grilli, "Commodity Price Stabilization and the Developing World." Finance and Development, vol. 14, (March 1977) pp. 8-11.

7. Dercon, S., 2000. Income Risk, Coping Strategies and Safety Nets. World Bank, background paper for the World Development Report 2000/01, WPS/2000.26, September.

8. Fraser, R. W., 1992. An Analysis of Willingness-To-Pay for Crop Insurance. The Australian Journal of Agricultural Economics 36(1), 83 . 95.

9. Grilli, Enzo and Maw Cheng Yang, 1988, "Primary commodity prices, manufactured goods prices, and the terms of trade in developing countries," World Bank Economic Review, 2, 1- 47.

10. HWA, E. C. (1979), Price Determination in Several International Primary Commodity Markets: A Structural Analysis, IMF Staff Papers, 26: 157-188. Morduch, J., 1995. Income Smoothing and Consumption Smoothing. Journal of Economic Perspectives (9), 103- 114.

11. Krug, C. A. and E. Quartey Papafio, World Cocoa Survey, Food and Agriculture Organization of the U.N., Rome, 1964.

12. Massel, B. F., "Price Stabilization and Welfare," Quarterly Journal of Economics, Vol. 83, No. 2, (May, 1979), pp. 284-297.

13. Nerlove, Marc, The Dynamics of Supply: Estimation of Farmers' Response to Price, The John Hopkins Press, Baltimore, Md., 1958.

14. Okorie, Aja, and David Blandford. "Demand and Prospects for Cocoa in the 1980's," Cornell Agricultural Economics Staff Paper, No. 79-21, Dept. of Agricultural Economics, July, 1997.

15. Waugh, Frederic V., "Does the Consumer Benefit from Price Instability?", Quarterly Journal of Economics, Vol. 58, No. 4 (August 1944), pp. 602-614; also, "Consumer Aspect of Price Instability," Econometrica, Vol. 34, No. 2, (April 1966), pp. 504-508.

\section{APPENDIX A}

Gains From Price Stabilization

From Massel's model, the gains from price stabilization are given by:

$$
\begin{aligned}
& \text { 1. Producer Gain: } \\
& \mathrm{E}(\mathrm{Gp})=\underline{(\alpha+2 \mathrm{~B}) \sigma \mathrm{xx}-\sigma \mathrm{yy}} \\
& 2(\alpha+B)^{2} \\
& \text { 2. Consumer Gain: } \\
& \mathrm{E}(\mathrm{Gc})=\underline{(2 \alpha+\mathrm{B}) \sigma \mathrm{yy}-\mathrm{B} \sigma \mathrm{xx}} \\
& 2(\alpha+B)^{2} \\
& \text { 3. Net Gain: } \\
& \mathrm{E}(\mathrm{G})=\frac{\sigma \mathrm{xx}+\sigma \mathrm{yy}}{\alpha(\alpha+\mathrm{B})}
\end{aligned}
$$

Where:

$\alpha=\quad$ Coefficient of producer price 


$\begin{array}{lll}\mathrm{B} & = & \text { Coefficient of consumer price } \\ \sigma \mathrm{xx} & = & \text { Supply Variance } \\ \sigma \mathrm{y} & = & \text { Demand Variance }\end{array}$

Empirical values of supply and demand variances used in estimating producer, consumer and net gains from price stabilization are calculated as follows:

Supply Variance ( $\sigma x x)$ from Producer Equation (Table 2).

$\sigma \mathrm{xx}=\operatorname{Var}\left(\alpha_{\mathrm{o}}+\alpha \mathrm{wW}+\mathrm{Q}^{\prime} \mathrm{Q}^{\prime}\right)$

$=\alpha \mathrm{w}^{2} \operatorname{Var}(\mathrm{W})+\alpha^{2} \mathrm{Q}, \operatorname{Var}\left(\mathrm{Q}^{\prime}\right)+2 \alpha \mathrm{wdQ}, \operatorname{cov}\left(\mathrm{W}, \mathrm{Q}^{\prime}\right)$

$\operatorname{cov}\left(\mathrm{W}, \mathrm{Q}^{\prime}\right)=\sigma \mathrm{Q}^{\prime} \mathrm{W}^{*} \sigma \mathrm{Q}^{\prime}, \sigma \mathrm{W}$

Where:

$\sigma \mathrm{Qw}=$ Correlation coefficient between $\mathrm{Q}^{\prime}$ and $\mathrm{W}$

$\sigma Q^{\prime}=$ Standard deviation of Q'

$\sigma \mathrm{W}=$ Standard Deviation of $\mathrm{W}$

$\alpha^{2} \mathrm{~W}=(.356)^{2}=.127$

$\alpha^{2} Q^{\prime}=(1.06)^{2}=1.124$

$\operatorname{Var}(\mathrm{W})=626.13$

$\operatorname{Var}\left(Q^{\prime}\right)=7952.92$

$\sigma \mathrm{Q}^{\prime} \mathrm{w}=.223$

$\sigma Q^{\prime}=89.18$

$\sigma \mathrm{W}=25.02$

$\operatorname{cov}\left(\mathrm{W}, \mathrm{Q}^{\prime}\right)=(.223)(89.18)(25.02)$

$=(497.58)$

$\sigma \mathrm{xx}=(.127)(626.13)+(1.124)(7952.92)+2(.356)(1.06)(497.58)$

$=79.52+8939.1+375.53$

$=9394.13$

Demand Variance (бyy) from Structural Demand Equation (Table 1)

$\mathrm{E}(\mathrm{Y})=\mathrm{E} \beta \mathrm{o}+\beta \mathrm{psE}(\mathrm{ps})+\beta \mathrm{ydE}(\mathrm{yd})+\beta \mathrm{QwbE}(\mathrm{Qwb})$

$\operatorname{Var}(\mathrm{Y})-\sigma \mathrm{yy}=\mathrm{E} \beta \mathrm{ps}\left(\mathrm{Ps}-\mathrm{E}(\mathrm{Ps})+\beta \mathrm{yd}\left(\mathrm{Yd}-\mathrm{E}(\mathrm{Yd})+\beta \mathrm{Qwb}\left(\mathrm{Qwb}-\mathrm{E}(\mathrm{Qwb})^{2}\right.\right.\right.$

$=\mathrm{E} \beta \mathrm{ps}^{2}\left(\mathrm{Ps}-\mathrm{E}(\mathrm{Ps})^{2}+\mathrm{E} \beta \mathrm{Yd}^{2}\left(\mathrm{Yd}-\mathrm{E}(\mathrm{Yd})^{2}\right.\right.$

$+\mathrm{E} \beta^{2} \mathrm{Qwb}\left(\mathrm{Qwb}-\mathrm{E}(\mathrm{Qwb})^{2}+2 \mathrm{E} \beta \mathrm{ps}(\mathrm{Ps}-\mathrm{E}(\mathrm{Ps}) \beta \mathrm{Yd}(\mathrm{Yd}-\mathrm{E}(\mathrm{Yd})\right.$

$+2 \mathrm{E} \beta^{2}(\mathrm{Yd}-\mathrm{E}(\mathrm{Yd}) \beta \mathrm{Qwb}(\mathrm{Qwb}-\mathrm{E}(\mathrm{Qwb})$

$=\beta \mathrm{ps}^{2} \operatorname{Var}(\mathrm{pS})+\beta \mathrm{Yd} \operatorname{Var}(\mathrm{Yd})+\beta^{2} \mathrm{Qwb} \operatorname{Var}(\mathrm{Qwb})$

$+2 \beta \mathrm{ps} \beta \mathrm{yd}$ cov (Ps, Yd) $+2 \beta \mathrm{ps} \beta \mathrm{Qwb}$ cov (Ps, Qwb)

$+2 \beta y d \beta Q w b \operatorname{cov}(Y d, Q w b)$

$\operatorname{cov}(\mathrm{Ps}, \mathrm{Yd}=\delta \mathrm{Ps}, \mathrm{Yd} * \sigma \mathrm{ps} \sigma \mathrm{Yd}=(.432)(55.21)(285.49)=6809.14$

$\operatorname{cov}(\mathrm{Ps}, \mathrm{Qwb})=\delta \mathrm{Ps}, \mathrm{Qwb} * \sigma \mathrm{Ps} * \sigma \mathrm{Qwb}=(.189)(55.21)(126.79)=1320.01$

$\operatorname{cov}(\mathrm{Yd}, \mathrm{Qwb})=\delta \mathrm{Yd}, \mathrm{Qwb} * \sigma \mathrm{Ps} * \sigma \mathrm{Qwb}=(.771)(285.49)(126.79)=27908.10$

$\beta \mathrm{ps}=.58 \quad \mathrm{Var}(\mathrm{Ps})=3,047.8 \quad \delta \mathrm{ps}, \mathrm{Qwb}=.189$

$\beta \mathrm{Yd}=.39 \quad \operatorname{Var}(\mathrm{Yd})=81,502.7 \quad \delta \mathrm{ps}, \mathrm{Yd}=.432$

$\beta \mathrm{Q} w \mathrm{~b}=.08 \quad \operatorname{Var}(\mathrm{Qwb})=16,075.2 \quad \delta \mathrm{Yd}, \mathrm{Qwb}=.771$

$\sigma \mathrm{ps}=55.21 ; \sigma \mathrm{Qwb}=126.79 ; \sigma \mathrm{Yd}=285.49$

$\sigma \mathrm{yy}=(.58)^{2}(3047.8)+(.39)^{2}(81502.7)+(-.08)^{2}(16075.2)$

$+2(.58)(.39)(6809.12)+(2(.58)(-.08)(27908.10)$

$+2) .39)(-.08)(27908.10)$

$=1025.58+12396.56+102.88+3080.45-1741.46$

$\sigma \mathrm{yy}=12,272.84$ 
Estimated gains from price stabilization using Massel's model and parameter estimates from study equations are given by:

1. Producer Gain:

$$
\begin{aligned}
& \mathrm{E}(\mathrm{Gp})=(\alpha+2 \beta) \sigma \mathrm{xx} \alpha \sigma \mathrm{yy} \\
& 2(\alpha+\beta)^{2} \\
& =\frac{[.022+2(.54)] 9394.13-.022(12,273.84)}{2(.022+.54)^{2}} \\
& 2(.022+.54)^{2} \\
& =\underline{10352.33-270.02=15953.02} \\
& \alpha=.022 \\
& \beta=.54 \\
& \sigma \mathrm{xx}=9,394.13 \\
& \sigma y y=12,273.84 \\
& \text { 2. Consumer Gain: } \\
& \mathrm{E}(\mathrm{Gc})=\underline{(2 \alpha+\beta) \sigma \mathrm{yy}-\beta \sigma \mathrm{xx}} \\
& 2(\alpha+\beta)^{2} \\
& =\frac{[2(.022)+.54] 12273.84-.54(9394.13)}{2(.022+.54)^{2}} \\
& =\underline{7167.92-5072.83} \\
& .632 \\
& =3315.02 \\
& \text { Net Gain: } E(G)=\frac{\sigma x x+\sigma y y}{Z(\alpha=\beta)} \\
& =\underline{9394.13+12273.84}=\underline{21667.97} \\
& 2(.022+.54) \quad \frac{21667.97}{1.124} \\
& =19277.55^{1}
\end{aligned}
$$

${ }^{1}$ Calculated net gain not exactly equal to producer gain plus consumer gain because of rounding. 